\title{
TOLERANCE IN INQUIRY-BASED LEARNING: BUILDING HARMONY AND SOLIDARITY IN STUDENTS
}

\author{
ABDUL WAHID ${ }^{1}$, D.Y.P. SUGIHARTO ${ }^{2}$, SAMSUDI ${ }^{3}$, \\ $\mathrm{HARYONO}^{4}$ \\ ${ }^{1}$ Universitas Islam Negeri Walisongo Semarang \\ ${ }^{2,3,4}$ Universitas Negeri Semarang
}

\section{Abstract}

This study aims to reveal how inquiry-based learning can be used as a strategy in building harmony and solidarity which, in turn, can instill tolerance values in students. It is a qualitative research involving Sekolah Alam Ungaran in Semarang Regency as its subject of study. The study employs in-depth interview, observation, and documentation. It uses triangulation of resources and methods to ensure data validity. Meanwhile, data analysis refers to the Miles and Huberman technique. The study finds that the tolerance values in inquiry-based learning in Sekolah Alam Ungaran are built through three types of activities: (1) self-development through routine activities, spontaneous activities, exemplary and conditioning; (2) integration into materials or courses, and (3) formation of school culture. Later, these findings are designed to be a model of inquiry-based learning to build harmony and solidarity in students.

Kajian ini bertujuan untuk mengungkapkan bagaimana pembelajaran berbasis inkuiri dapat digunakan sebagai strategi dalam membangun harmoni dan solidaritas yang dapat menanamkan nilai-nilai toleransi pada siswa. Penelitian kualitatif ini melibatkan Sekolah Alam Ungaran di Kabupaten Semarang sebagai subjek

Corresponding author; email: ${ }^{1}$ abdul_wahid@walisongo.ac.id, ${ }^{2}$ s_dyp@yahoo.com, ${ }^{3}$ samsudi@mail.unnes.ac.id, ffransharyono@mail.unnes.ac.id. 
penelitian. Penelitian ini menggunakan teknik wawancara secara mendalam, observasi, dan dokumentasi dengan triangulasi sumber daya dan metode untuk memastikan validitas data. Sementara itu, analisis data mengacu pada teknik Miles dan Huberman. Kajian ini menemukan bahwa nilai-nilai toleransi dalam pembelajaran berbasis inkuiri di Sekolah Alam Ungaran dibangun melalui tiga jenis kegiatan: (1) pengembangan diri melalui kegiatan rutin, kegiatan spontan, keteladanan dan pengkondisian; (2) integrasi ke dalam materi atau kursus, dan (3) pembentukan budaya sekolah. Temuan ini selanjutnya dirancang menjadi model pembelajaran berbasis inkuiri untuk membangun harmoni dan solidaritas pada siswa.

Keywords: education; inquiry-based learning, sekolah alam; student; tolerance.

\section{Introduction}

In the context of social life, diversity or pluralism often becomes a problem that can trouble social integrity. Failure in managing pluralism can be one of the factors triggering social conflicts, both those coming from narrow religious vested interests and those coming from cultural supremacy of certain groups of people.

In the last two decades, the social situation has been frequently tainted by violent incidents of radicalism. One of the incidents that has shaken the spirit of diversity in the country recently was the Surabaya Bombing on May 13-14, 2018, when one family bombed several churches (Hadi and Widiastuti 2018). Against this background, dissemination of tolerance values in plural society is a priority in order to maintain the national unity. Besides parents and society, schools also have an important and strategic role in instilling tolerance values in students. The formation of good character in general and of tolerant attitudes, in particular, is an integral role of educational institutions. To be able to carry 
out such a role and function, educational institutions must be able to provide instructional activities that support the internalization of tolerance spirit.

Functionally, multicultural issues that occur in a society can be solved with education. Success in educational world will have implications for the success in social life. Conversely, failure in educational world will also have implications for the failure in social life. Hence, the possible effort to do is by proposing systematic and methodological management in education. In this sense, humanistic and multicultural dimension should be developed in the learning process; that is, by promoting learning activities that appreciate differences among fellow human beings to realize peace and harmony in the social life order (Naim and Sauqi 2010, 205).

Promotion of tolerance values will not be effective if it stops at a mere theoretical level. Here, children must be involved to experience multicultural situations more repeatedly. Why is inquiry-based learning an option? By nature, children play while learning. They also have great curiosity towards phenomena that happen around them. This curiosity leads them to move dynamically to respond to the phenomena. They will observe and research almost everything they encounter. In this case, inquiry-based learning offers an implementation of social values, especially tolerance. This approach emphasizes the importance of giving students with comprehensive understanding through learning activities that provide concrete experiences, active involvement and knowledge building.

The inquiry-based learning model will make knowledge and values, that the children absorb, more meaningful. Some researches have shown that children are more satisfied and happy when learning with this model. Learning becomes more dynamic and is able to increase motivation to learn, curiosity, creativity 
and critical thinking towards the materials being studied. From course classification perspective, inquiry-based learning is often associated with natural sciences. However, it does not mean that this approach is not applicable in social sciences. In fact, some researchers, such as Ifeoma and Oge (2013), Siraj-Blatchford (2008), Bredekamp and Rosegrant (1992) in Megawangi (2004), and Novick (1996) have proven that inquiry-based learning can be applied in social sciences. Meanwhile, Al Sadi and Basit (2013) in her study of students in Oman concluded that education has a crucial role in promoting equality among religions and, in turn, is useful in suppressing intolerant attitudes.

This study highlights the inquiry-based learning in instilling tolerance values developed by Sekolah Alam Ungaran (Saung). The school is relatively new and quite attractive to urban educated people due to its innovation to create learning that is unique and outside the mainstream. Whether the school offers a mere different trend or it intends to create an alternative learning model that is innovative is a topic interesting to study. Findings of this study will be designed to become a model of inquiry-based learning that instills tolerance values.

This research is a field research with descriptive-qualitative approach. A qualitative approach in educational research will bring benefits as it is considered more appropriate to reveal various variables of a social problem comprehensively, such as in education. The approach will also open wider variables, not limited to certain hypotheses so that the findings will be closer to the truth.

Essentially, the application of qualitative method in the field of education aims to: (1) analyze and interpret facts and events in an educational process in the field as they are, i.e. in the context of space, time and natural educational environment, (2) describe an educational process comprehensively based on what 
really happens in the field, so that it can be used as a source for further studies concerning problems in conducting education and their solution, and (3) compile concepts and principles of education based on data, facts, and information from the field (Samsudi 2006).

In qualitative method, data are obtained from observation, documentation and in-depth interviews with snowball techniques. The data resources include school-related members, i.e. the principal, teachers, students, parents, and the surrounding community. To test the data validity, this research uses triangulation of resources and methods. Meanwhile, data analysis in this study is divided into two stages; namely during and after the research. In the end, the data analysis refers to the Miles and Huberman techniques which set three stages of analysis, i.e. (1) data reduction, (2) data presentation, and (3) conclusions or verification (Miles and Huberman 1992).

\section{The Importance of Tolerance}

In a heterogeneous society, differences are a necessity. Difference in views, attitudes, and behaviors cannot be avoided nor uniformed. The difference emerges due to various factors in each individual. Therefore, one possible thing to do in a pluralistic society is to form an attitude of mutual understanding and respect. It is with such differences that a beautiful color in life can be created.

The opposite attitude of tolerance is called intolerance. Intolerance is known as symbols of negative attitudes and behaviors in interactions between individuals. Various symptoms of such negative attitudes and behaviors can be identified, among others, as follows. (a) Scapegoating; that is, the practice of blaming a person or group for traumatic events or matters relating to social problems. (b) Bullying; that is, the use of physical capacity that perceives superiority of a person or group to insult, intim- 
idate or revoke the rights or status of others. (c) Stereotyping; that is, the practice of bringing an over-generalized belief about a particular category of people, usually of negative values. Later, learning activities meant to educate and instill tolerance values are carried out with case study through several stages. The stages are (1) narration of case, (2) identification of value, (3) literacy of norms, (4) affixation of consciousness and (5) internalization of value (Mulyana 2005).

Shaver's research conducted in New Zealand, a country with very little conflict, found that intolerant attitudes still exist in the country. The finding of his research showed that anti-Muslim and anti-Arab sentiments are quite obvious as they are widespread and substantially higher than anti-immigrant sentiments. It indicates that the intensity of religious commitment is closely related to the intensity of tolerant attitudes toward minority groups, including the Muslim minority. The finding also confirms the power of religion in increasing tolerant attitudes for peaceful community, which are often troubled by prejudice (Shaver et al. 2016).

In social life, tolerance must be established among religious followers since social clashes and disputes due to intolerant attitudes are believed to emerge very easily from religious sentiments. However, real tolerance should not be limited merely to religious life. Tolerance has a very broad aspect in its implementation. It may appear in every unit of social life, such as in the family, community, workplace, and school.

With reference to various conflicts in society, the scope of tolerance is actually very broad. It is not only limited to the religious domain although religion remains the most sensitive issue in a pluralistic society. Religion is only one part of tolerant life. Tolerance may have very broad coverage because it involves all attitudes and behaviors of individuals in relation to social 
interaction, in all aspects of human life. Hariyanto and Samani defined tolerance as an attitude to openly accepting other people from different levels of maturity and background (Hariyanto 2013). This argument implies that one should not discriminate against other people who have different levels of maturity and background than himself.

Various definitions of tolerance have been formulated by experts. UNESCO, for instance, defines tolerance as: "Tolerance is not an end but a means; it is the minimal essential quality of social relations that eschew violence and coercion. Without tolerance, peace is not possible. With tolerance, panoply of positive human and social possibilities can be pursued, including the evolution of a culture of peace" (UNESCO 1994).

Developing tolerance spirit and attitude is necessary for a multicultural society. Multicultural education should become the main concern by all elements in society. It is usually characterized by the following features. (1) Its aim is to form human of culture and create a civilized society. (2) It teaches noble values of humanity, national values, and ethnic (cultural) values. (3) It uses democratic methods that place high respect on differences and diversity of national and ethnic cultures (multiculturalist). (4) Its evaluation is based on the assessment of students' behaviors which include perceptions, appreciation, and actions towards other cultures (Maksum and Ruhendi 2009, 190-92).

In multicultural education, there are dimensions to be considered. Banks (2007, 83-84; Banks and Banks 2010) explained that multicultural education has six interrelated dimensions. (1) Content integration; that is, integrating various cultures and groups to illustrate fundamental concepts, generalizations, and theories in the course or discipline. (2) Knowledge construction process; that is, helping students understand cultural implications the course or discipline. (3) An equity pedagogy; that is, 
adjusting teaching methods to the students' learning style to facilitate their academic achievements that vary in terms of race, culture or social aspects. (5) Prejudice reduction; that is, identifying racial characteristics, determining their teaching methods and training groups to participate in activities and interact with all staff and students of different ethnicities and races to create an academic culture. (6) Empowerment of school culture and social structure; that is, strengthening school culture and social structures that support the realization of a proper multicultural atmosphere.

Technically, multicultural education can be used as an educational strategy possible to be applied or inserted in all types of course; that is, by positively responding the cultural differences that exist in each student, such as their ethnicity, religion, language, gender, social class, race, ability and age, so that the learning process becomes more effective and easier. Multicultural education is also important especially to train and build the students' character, so that they may practice democratic, humanist and pluralist attitude in their environment.

At the practical level, tolerance values that are important to be instilled as intended in this study refer to the formulation from the Ministry of Education and Culture, including (a) showing respect to others regardless of their age, religion, race and culture, (b) trying not to talk about someone's ugliness, (c) listening to others passionately without interrupting their talk, (d) speaking politely by using nice words, such as excuse me, please, sorry and so on, (e) allowing other people to worship freely, (f) trying not to impose the will on others, (g) accepting other people who have physical, religious or racial differences, (h) self-respect, and (i) respecting the privacy of others (Maznah et al. 2016, 18). These attitudes are important to instill in students early on in order to prepare future generation who has a foundation of noble character. 
The internalization of tolerance values in students is important since the early childhood. At this age, it will be relatively easy. However, this idea should be followed with concrete, programmed and sustainable steps. If it is not done so, the goal of the idea will never be achieved. The success of internalizing tolerance values in education requires learning strategies that are able to reflect the real life experiences. This can be realized by involving the students in real experiences of tolerance and intolerance actions.

\section{Inquiry-Based Learning}

Inquiry-based learning is considered a practical method for building connectivity between prior knowledge and scientific descriptions of nature (Panasan and Nuangchalerm 2010). In this learning model, students must be given the opportunity to appreciate and understand various forms of scientific inquiry. Besides, this model also refers to the way in which scientists study the nature and explain it based on evidences originating from their own studies.

Inquiry-based learning is related to the search for knowledge or understanding to satisfy curiosity, so that students may enliven their critical and creative thinking to solve problems (Nivalainen, Asikainen, and Hirvonen 2013). This learning model covers diverse activities, such as asking questions, testing the reliability of materials, books and other sources of information, investigating, reviewing what have been produced from experiments, using tools, analyzing and interpreting data, proposing answers, explaining, predicting, and communicating the findings. Inquiry also includes identifying assumptions, using logical and critical thinking, and considering alternative explanations.

In implementation, educators should first discuss and explain the principles of learning. Later, they develop one very common practice called "learning while playing". Learning while playing 
is usually interpreted as a context where children organize and make their own world, with regard to their involvement with various people, objects and symbols in their environment (DEEWR 2009).

One important aspect of inquiry-based learning is playing. Playing for early childhood provides a good opportunity for students to explore, recognize, negotiate, take risks and build meaning. The intellectual and cognitive benefits of the game have been found and documented. Children who are involved in a quality playing experience will develop good memory skills, language competence, and be able to regulate behavior guiding them to adapt to the learning climate in school (Bodrova and Leong 2005). Good quality of playing, for children, will spur the development of various aspects, such as intellectual, cognitive, memory, language, behavior and good learning abilities. Brain development in childhood will be greatly influenced by playing activities; the playing activities will form a structural design of the brain. Stimulation is also a significant aspect of brain development, while playing supports active exploration which helps build and strengthen brain pathways. Playing will increase flexibility and increase the potential for future learning. It does not occur in 'empty' situation, but in a physical and social environment (Lester et al. 2008).

Another important thing that can be said about this approach is that it provides a complete and comprehensive understanding to students through learning activities that uses concrete experience, active involvement and knowledge building. The model of inquiry-based learning will make knowledge and values the students absorb more meaningful. Moreover, some researches also show that this model brings learning satisfaction and joy to students. Learning becomes more dynamic and is able to increase learning motivation, curiosity, creativity and critical 
thinking towards the materials being studied. In the context of tolerance values, inquiry-based learning is seen able to be an effective and meaningful strategy in instilling tolerance values in students at an early age, also known as the golden age. This way, the success of this instilling will be an important foundation for the development of children's characters, especially the tolerance values, to be applied in their life.

\section{Subject of the Study}

Sekolah Alam Ungaran, hereinafter referred to as Saung, is geographically located in West Ungaran, around the slope of Ungaran Mountain. More specifically, it is at Jl. Ismaya Raya No. 57 Lorog, Lerep Village, West Ungaran Subdistrict, Semarang Regency. Saung is one of few nature-based schools in Central Java. It opens Early Childhood Education (PAUD) and Elementary School Education. Carrying out the motto From Nature to Create the Culture beyond the Future, Saung seeks to organize nature-based learning.

Saung is located at the corner of Lorog Lerep Village, right in the western part of the Ungaran Mountain slope. The school location is fairly difficult to reach because it is quite far from the highway. The only way to reach this location is by using a private vehicle. The land area owned by Saung is approximately $2,000 \mathrm{~m}^{2}$. Indeed, for a nature-based school, the width is considered inappropriate. Fortunately, since the location is close to Ungaran Mountain, the problem dealing with the width of the area is resolved. The mountain itself is part of the place of learning activities. The result of the interview with Istadi, the principal of the school, confirmed that efforts to expand the land area are now continuing in order to fulfill the ideal of the nature-based school.

Topographically, the land contour of this school is unlike schools in general, which are relatively flat. Due to its position 
on the slopes of Ungaran mountain, Saung is quite steep and hilly. However, the layout of the school is unique and planned quite well. It adjusts the contour of the land. The layout prioritizes safety and security factors of the school community, while betterment is still going on. Overall, the layout of this school can be said to adequately represent the characteristic of a nature-based school (Wahid 2017).

As a nature-based school, Saung brings learning activities to be connected with nature. It explores learning resources found in the surrounding environment. Unlike conventional schools where the portion of learning activities is more inside the classroom, Saung designs the activities outdoor, i.e. outside the classroom.

In practice, learning activities at Saung refer to the philosophy of constructivism. That is, students are guided and facilitated to search, explore and find facts. Later, they are required to assemble and build on their experience and knowledge with reference to the facts found previously. the strategy used by the school is discovery learning. With this in mind, Saung frees students to be themselves and develops their potentials to grow into human beings who are noble, knowledgeable and unique. In the learning practice, Saung frees them to explore, experiment and create their own potentials with the concept of fun learning. The learning activities can go through various kinds of boundaries may restrict their curiosity. Mulyasa $(2003,235)$ stated that inquiry is basically a way of realizing what has been experienced. This method places the students in a situation where they must involve in intellectual activities. This method requires them to process learning experiences into something meaningful in real life. Hence, this method can stimulate students to be productive, analytical and critical. 


\section{Internalizing Tolerance Values through Inquiry-Based Learning}

Efforts conducted by Saung in internalizing the tolerance value in students have been formulated in a learning cycle, namely learning in nature, learning from nature and learning with nature. Nature is a place, source and pleasant friend for learning. The nature or environment meant in Saung is the physical and social environment. All dimensions of children's life are a concern; it is through this physical and social environment that children observe, seek, find and absorb values of tolerance. Tolerance appears in this form of compassion not limited to fellow humans, but also fellow living beings and the surrounding world.

Physical management is the first thing to be considered by Saung. Classroom arrangement is designed to be integrated with the surrounding environment, i.e. in the form of saung or huts built semi-permanently. These huts are set up under a grove of trees with the aim of creating a pleasant learning atmosphere. Unlike conventional classes, there is no table or chair in Saung. The school only provides pedestal or mat. This way is intended to instill enthusiasm and willingness in students to share and tolerate with fellow friends when learning. There is no special place for each child. Students are free to move, and this idea also becomes a supporting factor for a more flexible learning.

Outside the huts or saung, physical and social environment is also developed as school facilities and learning resources. Saung applies a proportion of $70 \%$ outdoor learning practices and $30 \%$ indoor learning theories for lower classes, i.e. levels I to III. Meanwhile, higher classes, i.e. level IV to VI, have $60 \%$ outdoor learning practices and $40 \%$ indoor learning theories. In the lower class, habituation activities with exemplary gain a greater portion because children at this age are seen to have less verbal analytic ability. In the other hand, the portion of habitua- 
tion for children in higher class through practices can be reduced because their verbal analytic ability is seen to have been better.

The number of children in each study group is limited to and maximum of 15 students. Saung emphasizes a learning group consisting of few students. Every 15 children are handled by a teacher. It is noted that only class II has a total of 20 children or students; however, the class is managed by two teachers. This commitment is intended to make teachers more focused and effective in assisting children to learn. With few students in each class, the learning atmosphere will be more conducive and effective. From the tolerance side, this small class is very supportive of planting tolerant attitudes. The level of psychological friction between children is relatively small, so children can be conditioned to feel tolerant. The level of patience, the willingness to help and mutual respect can work well in learning activities.

In daily learning, the teacher also applies learning techniques in small groups. The class of 15 children is often divided into three to five groups. The teacher gives assignments to each group. This technique is used especially in outdoor learning. Each group is led by a chairman. The group chairmen are appointed alternately. That is, each child will later get a turn to lead his friends. In addition to improving children's academic ability, this technique is also seen as effective way in instilling leadership and tolerance values. By leading his friends, a chairman will be trained to listen and appreciate opinions of his friends, respect differences and sharpen his ability to unite or find a middle way for these differences.

In this school, diversity gets a great attention, one of which is seen in dressing. Unlike conventional schools that strongly give emphasis on school uniforms, Saung offers freedom in dressing. It is only once a week that children are required to wear school uniform, while in the remaining days children are allowed to 
dress freely. The school uniform is meant to show the school identity and the love for the alma mater. Meanwhile, the purpose of this free dressing policy is to develop a spirit of diversity in unity. This way, students are instilled in themselves to implement tolerant attitudes and respect. Uniformity is seen inappropriate for nature-based schools, which emphasizes diversity.

Other finding shows that inquiry-based learning model applies an integrated learning method called spider-web and thematic learning. The method developed here is in the form of exemplary, habituation, mother tongue method and learning with nature. Physical and social environment is utilized as a means and source of learning. Meanwhile, the promotion of tolerance values is instilled through various activities such as (1) self-development through routine activities, spontaneous activities, exemplary, and conditioning, (2) integration into courses, and (3) formation of school culture.

Self-development is an effort to implant self-development on students in the form of several activities, such as routine activities, spontaneous activities, exemplary and conditioning. These self-development activities are the initial basis for character building, especially tolerance values. If this stage doesn't work well, the other stages will be difficult. In general, inquiry-based learning in the form of routine activities runs well and sufficiently, and the students can enjoy the learning activities. They look happier and freer in learning. The burden and tension in learning can be reduced because learning situations are created joyfully and in a relaxed way. However, sometimes there is still a slight overlap and repetition of the theme. This creates an impression of repetitive activities, so time allotment and material become less effective. Meanwhile, spontaneous activities are seen useful to be a breaker in the teaching and learning activities. It should be admitted that inquiry-based learning requires skills and abil- 
ities of the teacher to manage time and activities well. Spontaneous activities that arise from the students are sometimes quite effective to break the deadlock during classroom activities. However, if the teacher is unable to connect such spontaneous activities with the learning goals to be achieved, the activities will become less meaningful.

Later, from exemplary and conditioning aspect, the teachers at Saung have developed examples or models of attitudes and behaviors that gave a positive influence in the character building, especially tolerance values. Some habits exemplified are such as smiles and greetings to school citizens, eating, drinking, dressing and discipline in the school. Role-modelling is also instilled in learning in the form of respect for differences of opinion, ways of expressing the opinions and leading friends to learn. The example of the teachers can also be a role model for children although, to some extent in the lower classes, there is a clash between the values they receive at school and those at home. To bridge this gap, the school periodically holds meetings with the parents or students' guardians.

Integration into courses or materials is considered to be a central stage of inquiry-based learning activities to instill tolerance values in students. Planning, implementation, and evaluation of the learning activities are found in this stage. In general, based on sufficient teaching experiences, the teachers can plan the inquiry-based learning well. Spiderweb and thematic model are the choices of this school. The nine tolerance values are formally designed and implemented in this stage. The activities that go through this stage include: assessing and linking the standard of competence and the basic competence, including the tolerance values in the syllabus, creating active learning, helping the students recognize and instill tolerance values and evaluating the learning activities that involve tolerance content. 
The stages mentioned above can be carried out by the teachers by referring to the learning experience in previous years. The teachers must also discuss and consult the difficulties faced both with each other and with the school principal. In general, the the making of interrelationship between the standard of competence and the basic competence can be done, including the syllabus. However, there are some difficulties concerning the implementation. This is caused by several factors; that is, not all teachers have an academic qualification as elementary school teacher. Consequently, not all of them master the materials comprehensively. If their academic background is from mathematics education, for example, their mastery of the concepts and applications of material other than Mathematics is relatively weak. This case, in turn, can cause difficulties in implementing the integration of various materials in the spider-web pattern. The mastery of background-related materials becomes more dominant than background-unrelated materials. Another problem deals with the development of science and the rapid flow of information that sometimes make the teacher's response, in terms of course integration, a bit late. Assignment given to students sometimes becomes less relevant if the teachers do not update the actual information. Updating the Information and knowledge is a necessity in this spider-web and thematic model. Continuous capacity building is also an important issue that must be taken into account by the teachers and, especially, the principal.

In general, efforts to build values through inquiry-based learning at Saung, besides its limitations, are running quite well. The variety of activities proposed can contribute positively in shaping the students' character, especially related to tolerance values. The instilling of tolerance values through various activities in this nature-based school looks more meaningful because children are conditioned in a concrete learning environment. 
Tolerance values are absorbed more quickly by the children because they experience immediately, i.e. learning by doing.

The making of school culture in Saung can be grouped into four pillars. (1) The first is morality or akhlaq that is developed both in learning activities and in the school environment through habituation and role modeling. (2) The second is leadership that is developed during the learning process in small groups in order to foster confidence, harmony and solidarity. (3) The third is logic and scientific mind that are developed through discovery learning to foster a sense of love for others and the surrounding environment. Finally, (4) the forth is entrepreneurship that are developed through periodic bazaars in schools by displaying the works of students to foster independence, pride and solidarity. Those four pillars are developed through the system building, conditioning, modeling and habituation. Based on the writer observation, it can be concluded that the integration and the building of school culture in Saung are quite successful. This integration represents a unique pattern of nature-based schools in creating and instilling character, especially tolerance values, in students. There, tolerance values do not run rigidly and theoretically because the values can be embodied in daily practice in school. Learning activities both inside and outside the nature seem to give a deeper impression of tolerance values being developed.

The social values of rural communities where Saung is located are also a concern in this study. The students are always instilled in themselves social manners known as unggah-ungguh to help them socialize around the school environment. This effort is a form of conservation of social and cultural values initiated by the school so that students will not be deprived of their cultural roots.

What have been developed by Saung looks relevant to Banks and Maksum's views. The introduction to tolerance values in an 
effort to build harmony and solidarity among students contains and integrates various dimensions that should be developed further in multicultural education.

While in conventional schools tolerance values are often stopped at the theoretical level and less relevant examples, in Saung all school citizens will be conditioned to find tolerance values and other noble characters in concrete situations. Each will be directly involved though sometimes clash is inevitable. Each citizen will negotiate in order to find a meeting point of the clash of values faced. This small number of students in one classroom is, in fact, sufficiently supportive to create a proper learning situation to cultivate tolerance values. Because of this small number, teachers are usually not faced with value conflicts between students on a broad scale. In higher classes, for example, the teachers may use the following steps: case narrative, identification of values, norm literacy, affixation of consciousness, and internalization of values. These steps will make tolerance values more deeply entrenched. Meanwhile, in lower classes, these steps have not been effectively implemented. Here, the teacher gives more emphasis on exemplary, conditioning and habituation.

Weakness in Saung is certainly inevitable. Indeed, the school itself is not the only party that contributes and is fully responsible for the internalization of tolerance values. There are family and community that also contribute and are responsible for the formation of children's character, especially tolerance values. Furthermore, according to the teachers, social media is one of the many factors very likely to disrupt the implementation of tolerance values. The use of electronic devices, e.g. gadgets, without parental supervision and control is another challenge. However, such devices can also be a means and source of learning if used appropriately under the parents' control. 
Another hindering factor is the social culture that is not fully predictable and controlled with regard to character building, especially tolerance values in students. Ideally, the community also has a responsibility in educating and building the noble character in children. However, such an expectation may not be fulfilled by members of society. Social, economic and educational background will determine their decision whether to contribute to the implementation of the tolerance values. If the members of community are aware of this condition, then it will give a positive contribution to the development of tolerance values for children. On the contrary, even though the family and school have endeavored to educate children but the community does not support this agenda, then all efforts made by the family and school maybe less impactful.

The role of family in planting tolerance values is obvious. However, this factor still needs to be coordinated with the school through routine meeting activities with parents. On the hand, the surrounding community of Saung is relatively supportive to the implementation of tolerance values as it is located in a rural area. However, the same condition may not happen as students live in different communities in their hometown. This factor seems to be another problem for students.

Despite the advantages and disadvantages described above, the concept developed by Saung has proven to survive for ten years. Of course, ideological resilience is highly needed to maintain the identity as a nature-based school amid the challenge of capitalization in educational world, in which many educational institutions are competing for quantity. As a school with a natural concept, Saung can be an alternative in the midst of some people's dissatisfaction with conventional school models.

In the end, the findings of this study confirm a model for instilling tolerance values through inquiry-based learning to build 
harmony and solidarity among students. This model may also be developed in other educational institutions. The offer of this model is described in figure 1 .

Figure 1

The model of internalization of tolerance values through inquiry-based learning

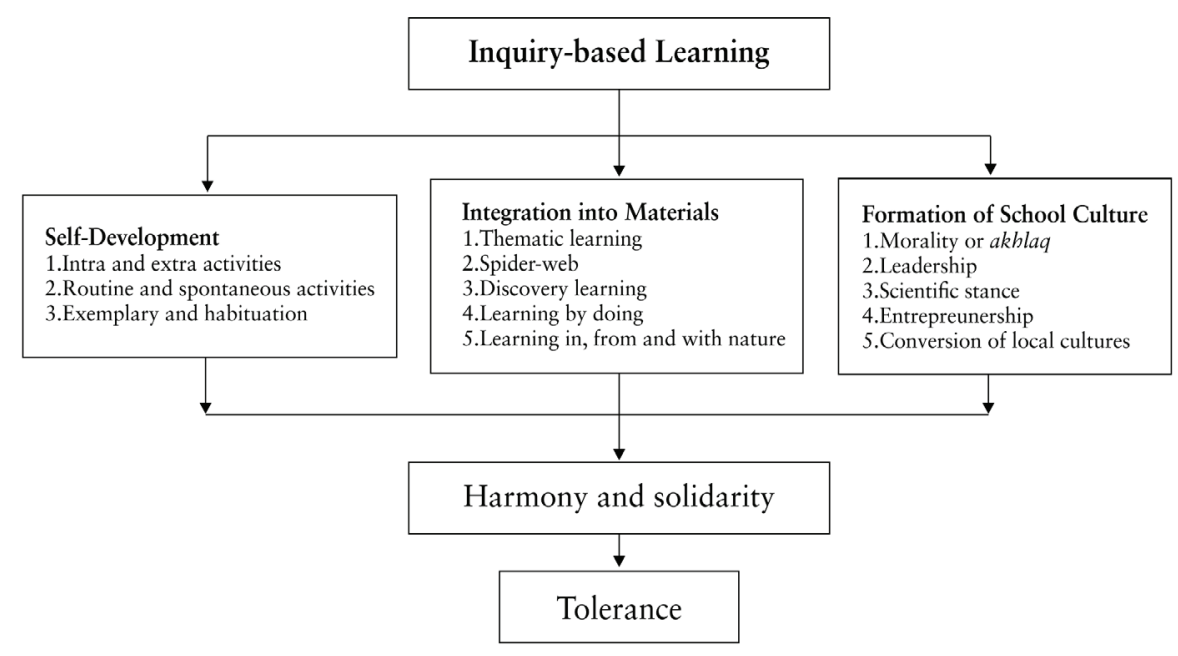

\section{Conclusion}

This study finds that internalization of tolerance values in Saung is carried out through inquiry-based learning. Its implementation is done by applying an integrated learning method called spider-web and thematic learning. Later, the method developed by Saung include exemplary or role modeling, habituation, mother tongue method and learning with nature. Physical and social environment are utilized as a means and source of learning at once. Meanwhile, tolerance values are internalized through various activities, such as (1) self-development through routine activities, spontaneous activities, exemplary and conditioning; (2) integration into materials or courses; and (3) formation of school culture. The methods developed by Saung can 
be a reference to build harmony and solidarity in students. This harmony and solidarity are later expected to be able to develop tolerance values. Further, the findings of the study offer a model of internalization of tolerance values through the inquiry-based learning that can be applied and developed in other educational institutions.

\section{Bibliography}

Banks, James A. 2007. Educating Citizens in a Multicultural Society. New York and London: Teachers College Press.

Banks, James A., and Cherry A. McGee Banks. 2010. Multicultural Education: Issues and Perspectives. Hoboken, NJ: Wiley Publishing.

Bodrova, Elena, and Deborah J. Leong. 2005. "Uniquely Preschool: What Research Tells Us about the Ways Young Children Learn.” Educational Leadership 63 (1).

Bredekamp, Sue., and Teresa Jane Rosegrant. 1992. Reaching Potentials : Appropriate Curriculum and Assessment for Young Children. Washington, DC: National Association for the Education of Young Children.

DEEWR. 2009. Belonging, Being \& Becoming: The Early Years Learning Framework for Australia. Canberra: Department of Education Employment and Workplace Relations (DEEWR).

Hadi, Nur, and Rina Widiastuti. 2018. "Begini Kronologi Ledakan Bom Di Surabaya." Tempo.Co.

Hariyanto, Muchlas Samani. 2013. Konsep Dan Model Pendidikan Karakter. Bandung: Rosda Karya.

Ifeoma, Olibie Eyiuche, and Ezeoba Kate Oge. 2013. "Effects of Guided Inquiry Method on Secondary School Students' Performance in Social Studies Curriculum in Anambra State, Nigeria." British Journal of Education, Society \& Behavioural Science 3 (3): 206-22. doi:10.9734/ 
BJESBS/2013/3300.

Lester, Stuart, Wendy Russell, Play England (Project), and National Children's Bureau. 2008. Play for a Change: Play, Policy and Practice - A Review of Contemporary Perspectives. Bristol: Play England.

Maksum, Ali, and Luluk Yunan Ruhendi. 2009. Paradigma Pendidikan Universal Di Era Modern Dan Post-Modern : Mencari Visi Baru Atas Realitas Baru Pendidikan Kita. Yogyakarta: IRCiSoD.

Maznah, Nana, Agus M Solihin, Rita Pranawati, Yuwono Tri Prabowo, Mohamad Roland Zakaria, Lilis Hayati, and Sri Lestari Yuniarti. 2016. Seri Pendidikan Orang Tua: Menumbubkan Sikap Toleran Pada Anak. Kementerian Pendikan dan Kebudayaan.

Megawangi, Ratna. 2004. Pendidikan Yang Patut Dan Menyenangkan: Penerapan Teori Developmentally Appropriate Practice (DAP). Jakarta: Indonesian Heritage Fondation.

Miles, Matthew B., and A Michael Huberman. 1992. Analisis Data Kualitatif. Jakarta: UI Press.

Mulyana, Rohmat. 2005. Case-Based Value Learning: A Challenging Issue for Teaching Religion in Indonesia. Bandung: UPI.

Mulyasa, E. 2003. Kurikulum Berbasis Kompetensi: Konsep Karakteristik, Dan Implementasi. Bandung: Rosda Karya.

Naim, Ngainun, and Achmad Sauqi. 2010. Pendidikan Multikultural Konsep Dan Aplikasi. Yogyakarta: Ar-Ruzz Media.

Nivalainen, Ville, Mervi A. Asikainen, and Pekka E. Hirvonen. 2013. "Open Guided Inquiry Laboratory in Physics Teacher Education." Journal of Science Teacher Education 24 (3). Springer Netherlands: 449-74. doi:10.1007/s10972012-9316-x. 
Novick, Rebecca. 1996. Developmentally Appropriate and Culturally Responsive Education: Theory and Practice. Oregon: Child and Family Program.

Panasan, Mookdaporn, and Prasart Nuangchalerm. 2010. "Learning Outcomes of Project-Based and Inquiry-Based Learning Activities." Journal of Social Sciences 6 (2): 25255.

Sadi, Fatma H. Al, and Tehmina N. Basit. 2013. "Religious Tolerance in Oman: Addressing Religious Prejudice through Educational Intervention." British Educational Research Journal 39 (3). John Wiley \& Sons, Ltd: 1-26. doi:10.108 0/01411926.2011.652071.

Samsudi. 2006. Desain Penelitian Pendidikan. Semarang: Universitas Negeri Semarang Press.

Shaver, John H., Geoffrey Troughton, Chris G. Sibley, and Joseph A. Bulbulia. 2016. "Religion and the Unmaking of Prejudice toward Muslims: Evidence from a Large National Sample." Edited by Michiel van Elk. PLOS ONE 11 (3). Public Library of Science. doi:10.1371/journal. pone.0150209.

Siraj-Blatchford, Iram. 2008. "Understanding the Relationship between Curriculum, Pedagogy and Progression in Learning in Early Childhood." Hong Kong Journal of Early Childhood 7 (2): 6-13.

UNESCO. 1994. Tolerance: The Threshold of Peace. Paris: The United Nations Educational, Scientific and Cultural Organization.

Wahid, Abdul. 2017. Penanaman Nilai-Nilai Toleransi Melalui Pembelajaran Berbasis Inkuiri Di Sekolah Alam Ungaran. Semarang: LP2M UIN Walisongo. 